\title{
The legacy of the Nixon years
}

A few hours before he announced his resignation as President of the United States, Richard Nixon vetoed the appropriations bill for the Environmental Protection Agency because he considered it to be inflationary. It was a symbolic last act for an Administration which spent a good deal of time doing battle with Congress over spending priorities. Colin Norman discusses how, for that small section of the population known as the scientific community, which has often been caught in the middle of the budgetary battle, Nixon's last veto was a reminder of what has passed and probably a taste of things to come.

IN his five and a half years in the White House, Nixon did not exactly win the undying support of scientists for his handling of scientific affairs. In fact, throughout his Presidency, cries of alarm from parts of the scientific community have been clearly audible above the background grumblings from most of academe. Among other things, the departed president and his lieutenants have been accused of plunging science into a financial crisis, of relegating some scientific disciplines to second place in the world pecking order, of failing to foresee situations in which science and technology could have been marshalled to help out (such as the energy crisis) and even of ignoring science completely.

The record, however, is a good deal better than many of the criticisms allow, and a good case can be made for the argument that some of the disquiet in the scientific community has its origins in events which took place well before Nixon set foot in the oval office. And it can equally well be argued that many of the science policies and institutional arrangements laid down by President Nixon will survive long after his departure.

Underlying most of the criticisms of Nixon's stewardship of the scientific enterprise is the fact that federal expenditures on science and technology during the past five years have increased at a rate barely sufficient to keep pace with inflation, and in some cases funding has even declined. On top of that, the Administration has gone for some of the scientific community's most cherished programmes, of which biomedical training was perhaps the most prominent. And the final straw came early last year when Nixon announced that he no longer needed a full-time science adviser in the White House, so he abolished that post along with the Office of Science and Technology and assigned some of its duties to the Director of the National Science Foundation.

Thus, the Nixon Administration's policies were clearly not designed to bring joy to the country's science and engineering laboratories. Nevertheless, scientists and technologists have fared rather better than their colleagues in many other disciplines, and the federal budget for science and technology, which stands at nearly $\$ 19,000$ million $(\$ 4,600$ million more than it was five years ago) is immense by any measure.

When the Nixon Administration came to power, the unquestioned growth of the science budget which took place during the Eisenhower and Kennedy Administrations had already come to a virtual halt. Thus, the first couple of years of so of Nixon's tenure were marked by painful adjustment from a period of burgeoning growth in science budgets to a period of almost static funding. One consequence was that the job market for scientists rapidly became very tight just when record numbers of scientists were emerging from the academic pipeline, a situation which did little to enhance the new Administration's standing in the eyes of the academic community.

The Administration's response was to cut back on funding for programmes designed to increase the supply of scientists and technologists. In 1971, for example, the proposal was made to eliminate the National Science Foundation's institutional support programme

Ford: inherits unhappy science community

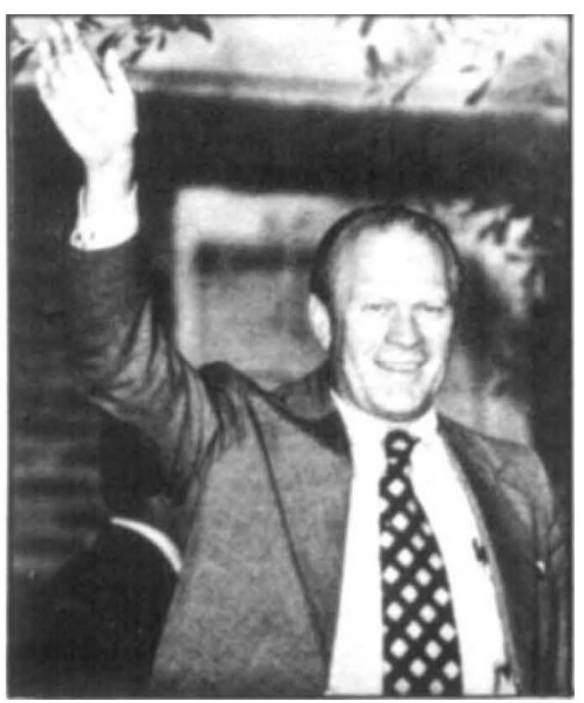

and to phase out its graduate training programmes. Since those two items were highly cherished sources of funds for universities, which were then facing huge financial deficits, the Administration's academic support slipped a few more notches.

But the budget announced in January 1971 represented, for the first time since 1968, a real increase in federal support for research and development. This was carried through with another boost for science and technology in the budget announced a year later. But, in January 1973, just after his re-election, Nixon slammed the brakes on public expenditure and withheld considerable sums of money promised in the preelection spending spree, with the result that funding for science again took a hammering. Nixon's support in the scientific community hit another low.

Finally, the budget announced just six months ago promised another round of increases in research and development expenditure, chiefly for the development of energy resources and for the Department of Defense.

The overall pattern of expenditure has therefore been one of stagnation, growth, cutbacks and growth-a situation which has not been conducive to university planning, and which has been unsettling for those who are forced to depend on the government for research grants. Whether or not the fabric of science in the United States has been damaged in the process, is, however, open to question.

The upshot of this slow and sporadic growth in the science budget has been to force a number of painful priority decisions in the basic sciences, as, for example, in space research where a number of promising satellite missions have been dropped, the High Energy Astronomy Observatory has been considerably scaled down in cost and performance and other missions have been deferred to accommodate development of the shuttle in a tight overall budget.

Similarly, particle accelerators have been shut down in order to accommodate the rapid growth in the budget of the National Accelerator Laboratory, and many research grant applications which have been designated as scientifically worthwhile by peer review groups at the National Institutes of Health have gone unfunded for lack of money. In the days of burgeoning growth, such painful choices probably not have been needed.

It has been in the biomedical science community, however, that the cries of anguish over the Administration's science policies have been loudest, and once again, the problems have been 
White House science adviser Guyford Stever (left) and Edward E. David, jun. (right).

exacerbated by a painful transition from periods of rapid growth to stagnation.

Superimposed on the situation, however, is the fact that in the past three years two highly publicised crusades-against cancer and against heart disease-have been launched and enthusiastically supported by both Congress and the Administration. The result has been that the budgets of the National Cancer Institute and the National Heart and Lung Institute have been allowed to grow relatively rapidly, while other NIH institutes have been held back so that many are now receiving less money than they got in 1968. Moreover, biomedical scientists both at NIH and in the Universities have complained bitterly that the Administration has been trying to run the cancer and heart programmes like NASA-style operations to land men on the moon by highly targeted research programmes which have drawn money away from basic research.

On top of all those complaints, the biomedical community has been upset by repeated vetoes by President Nixon of the appropriations bills for the Department of Health, Education and Welfare, which have held up funds for months, and which have kept funding at the levels proposed by the Administration rather than at the more generous levels approved by Congress.

These funding decisions and policy changes have not, however, been taken entirely in a vacuum, for $\mathrm{Mr}$ Nixon has also made substantial changes in the science policy machinery in the top echelons of the federal government. In fact, it is those changes which have done most to upset the elder statesmen of the scientific community.

When he arrived in the White House, Nixon inherited an extensive science policy apparatus whose origins dated back to the second World War, but when he departed last week, virtually none of it was left intact.

On the President's immediate staff was a science adviser, and a small policy office called the Office of Science and Technology which provided him with staff support. Lines to the scientific community were kept open by means of the President's Science Advisory Committee, chaired by the science adviser, and filled with a raft of luminaries from the universities. Nixon appointed Lee A. DuBridge, President of MIT as his first science adviser.

DuBridge and the Office of Science and Technology never became a powerful force in the Nixon White House, however, partly because President's

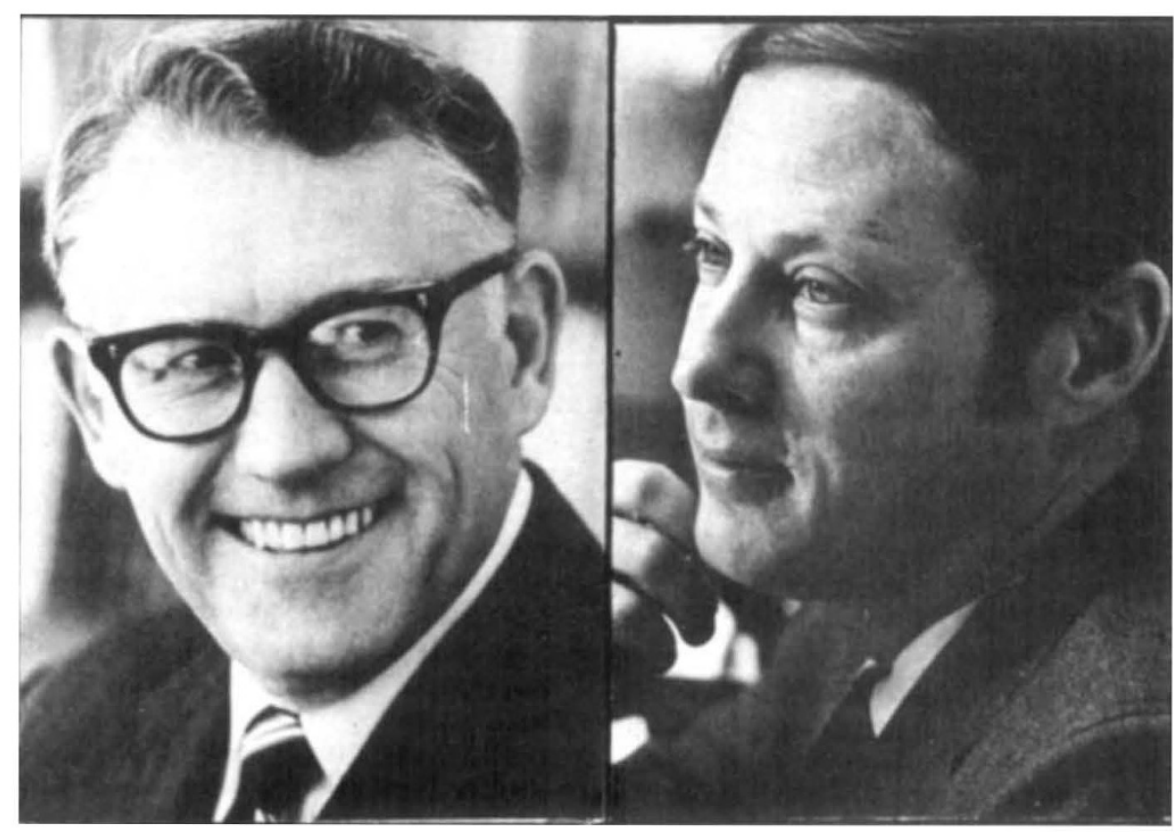

Science Advisory Committee took a number of stands on military matters which were in direct opposition to the Administration's policies, and partly because the rest of the White House just wasn't interested. And, as the influence of the science apparatus waned, the power of the New Office of Management and Budget (OMB) increased, so that it is now the focal point through which White house policy is conveyed to the departments and agencies. It wields tremendous power through the budgetary process.

DuBridge was eventually succeeded by Dr Edward E. David, jun., an engineer from Bell Labs, who departed in January last year after trying to interest the rest of the White House in science, with little success. Within two weeks of David's departure, Nixon scrapped the Office of Science and Technology, the post of Science Advisor to the President and the President's Science Advisory Committee, and designated the Director of the National Science Foundation, Dr $\mathbf{H}$. Guyford Stever, as science adviser to the White House.

Stever has since established in NSF a science policy office and an energy policy office, and he has been given a budget three times larger than that of the defunct Office of Science and Technology. He has also established lines to $\mathrm{OMB}$, and is generally credited with doing a commendable job, given the limits to his power.

The changes irked many scientists, however, who felt that science had been downgraded in national affairs, and many people have also criticised the fact that Stever has specifically been given no mandate to advise on military technology. In response to such complaints, Dr Philip Handler, President of the National Academy of Sciences, established recently a special (c) 1974 Nature Publishing Group blue ribbon panel under the chairmanship of Dr James Killian, Eisenhower's first science adviser, to look into the workings of the present science policy apparatus.

Not surprisingly, the Killian panel recommended that a science advisory council should be re-established in the White House, and that the present arrangement is unsatisfactory since Dr Stever, being head of a small science agency, is not in a strong enough position to orchestrate the vast federal science bureaucracy. Since there was absolutely no chance that Nixon would reinstate the post in the White House, the recommendations were clearly aimed at his successor.

Thus, President Gerald Ford has inherited an unhappy scientific community, a strong feeling among the scientific establishment that science should be reinstated in the White House, and a host of problems such as the energy crisis.and food shortages which will require large injections of science and technology.

Clearly, the science policy apparatus is not going to be one of Ford's immediate concerns, and little change can be expected in the short term. Ford himself has said that his immediate concern is to curb inflation, however, and that, indirectly could have a bearing on science.

Ford is a self-confessed fiscal conservative, believing in balanced budgets and decreased federal expenditures. Since only a relatively small proportion of the federal budget can be decreased -the vast majority of the budget is for such items as salaries, pensions and welfare payments which cannot be tinkered with-and since science expenditures mostly fall into the controllable category, the pressure on the science budget is unlikely to decrease under President Ford. 